\title{
Flint economy in the Pyrenees: A general view of siliceous raw material sources and their use in the Pyrenean Gravettian
}

\author{
Pascal Foucher \\ UMR 5608 TRACES - Université de Toulouse Jean Jaurès et Service Régional de l'Archéologie - DRAC \\ Midi-Pyrénées, France. Email: pascal.foucher@culture.gouv.fr
}

\begin{abstract}
:
The aim of this article is to present a very general view of siliceous raw material sources in the central Pyrenees, with support from recent bibliographic references. To illustrate the use of these materials in the Upper Paleolithic, we chose the example of the Gravettian occupation of Gargas Cave (Hautes-Pyrénées, France). Finally, we describe a few economic characteristics of the Pyrenean region, which are distinct from the Perigordian context in several ways.
\end{abstract}

Keywords: Gravettian; flint economy; Pyrenees; raw material sources; Lepidorbitoide flints; lithic industries

\section{Introduction}

Our knowledge of flint procurement sources in the Pyrenean context has become increasingly precise over the last twenty years, drawing on the work of pioneers such as Louis Méroc $(1947 ; 1953)$ and Robert Simonnet $(1981 ; 2003)$. (For the early historiography on this topic, see S. Lacombe's doctoral thesis (1998).) In the 1990's, research was conducted in the framework of the collaborative program entitled Lithothèque régionale, directed by $\mathrm{P}$. Chalard (1994-1996) and then F. Briois (1997-1999), but this work remains largely unpublished (Briois et al. 1997; Briois 2000). The doctoral thesis of S. Lacombe (1998) on the Late Glacial lithic industries of the Pyrenees presents an updated synthesis of both the siliceous material resources and their use in the Magdalenian and Azilian periods. The most recent articles by R. Rimonnet $(1999 ; 2003)$ present a synthesis of his work and complement his lithothèque (raw material reference collection) constituted through field surveys conducted over nearly 50 years. This reference collection is kept at the TRACES laboratory (UMR 5608 of the University of Toulouse Jean Jaurès). For interested readers, we provide most of R. Simonnet's scientific works on the characterization of Pyrenean siliceous raw materials. These include: his general synthesis articles (recent and earlier: 1981, 1996, 1999a, 1999b, 2002, 2003), in which there are paradoxically very few petrographic or geological analyses, as well as a micro-paleontological description by J. Villatte "that could serve as an inventory of

Published by the School of History, Classics and Archaeology, University of Edinburgh ISSN: 2055-0472. URL: http://journals.ed.ac.uk/lithicstudies/

This work is licensed under a Creative Commons Attribution 2.5 UK: Scotland License. 
the bioclasts of Danian flint"); and his earlier articles on more general subjects $(1967,1969$, 1973, 1976, 1982, 1985) or thematic topics (e.g. Paleolithic portable art: 1990), in which there are a few analyses of flint, or studies inserted within monographs (Mauran, La Vache: 1994, 2003). Recent research has drawn largely on petro-archaeological and geological analyses, such as that of lepidorbitoide flints (Séronie-Vivien \& Foucher 2006; Séronie-Vivien et al. 2012). (There are also a few university theses, at the Master's level, for example, Solène Caux, Guilhem Constans, Théo Minet.) The efficacy of these analyses has been demonstrated and they have revealed the complexity of Pyrenean lithic resources. Finally, the collaborative project led by P. Fernandes, contributing to the preceding research questions on a transregional scale, should provide a cartographic and archeo-petrographic database that will be very useful to prehistorians and provide an opportunity to remobilize research in the Pyrenees (Fernandes et al. 2013).

\section{Flint from the Petites Pyrénées and Plantaurel (central Pyrenees)}

The Petites Pyrénées and Plantaurel (their eastern extension) are one of the largest sources in terms of their geographic extension (Figure 1). They have furnished very diverse flint types (Danian, Paillon, Montsaunès, Foix-Berdoulet of Urgonian in the Foix basin, "black of Couterets", "brecciated flint of Pellegrin-Jean Nègre", "flint with charophytes": cf. Simonnet 1981; 2003).

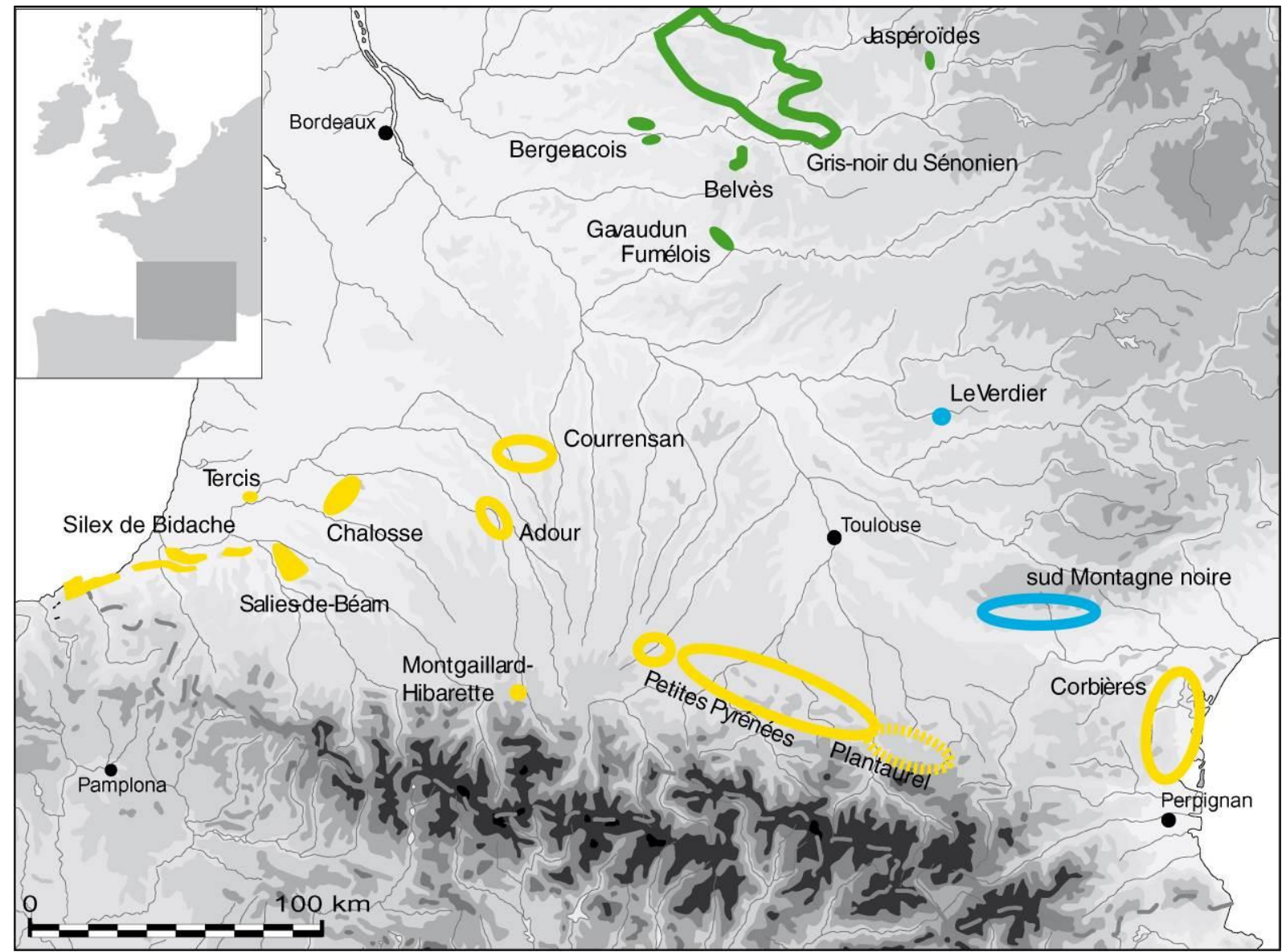

Figure 1. Map of flint sources in the Pyrenees. (From R. Simonnet, Ch. Normand, M. et M.-R. Séronie-Vivien, F. Bon, A. Tarriño, A. Morala, A. Turq, P.-Y. Demars, F. Briois, S. Grégoire).

- "Blue" flint, originating from the Danian formations is "a smoky, and especially blueish, translucent flint used throughout time and known by the local populations by this 
name. Prehistorians called it "chalcedonious". Its appearance is similar to the so-called "Tertiary" flints of other regions" (Simonnet 1999b). It is a very ubiquitous and found throughout the Petites Pyrénées and Plantaurel chains. S. Lacombe (1998) distinguished, as did R. Simonnet for a time, the "Blue" and "Smoky" types based on colorimetric and morphological data, the latter having much smaller useable volumes and traversed by numerous tectonic fractures.

- The Danian formations of the Petites Pyrénées and Plantaurel formations furnished other flint types similar to the "Blue", but with other features. We can cite the types designated by R. Simonnet as: "Mixed", "Saint-Michel", "Dôme d'Aurignac", etc.

- A specific flint a "blond" flint type, originating from the Danian formations of the Dôme d'Aurignac, was identified and found flaked in the Aurignacian of Tuto de Camalhot (Bon, Simonnet, Vézian 2005). It is a "very good material in the Pre-Pyrenees context. It is found in the form of regular blocks with a diameter greater than $10 \mathrm{~cm}$ and is fine-grained with a homogeneous texture".

- Paillon flint, originating from Maastrichtian formations (Saint-Martory, HauteGaronne), was described in the late 19th century (Leymerie 1881). Though it is a very characteristic and easily identifiable flint, no detailed petrographic analysis of it has yet been realized.

- Foix-Berdoulet flint, originating from the Urgonian formations of the Foix region. Other flints have been observed in the Lias and Albian-Aptian formations (according to Simonnet).

- Montsaunès-Ausseing flint originates from Maastrichtian formations. It is characterized by a high density of foraminifera and orbitoids (according to R. Simonnet). We find it localized in the southern part of the Boussens water gap (Montsaunès, Ausseing Mountain: see Figure 2). We presented a precise analysis of it when the Tarté flint was found and defined (Séronie \& Foucher 2006). This latter, which contains many lepidorbitoides was defined based on the archaeological assemblage recovered during the early excavations at Tarté (Aurignacian and Gravettian archaeological site). Its intrinsic characteristics (structure similar to that of the Montsaunès-Ausseing flint and cortex type) and the large quantity of it flaked at the site, suggest that the procurement sources must be nearby, probably in the Boussens water gap zone, which is highly adapted to their formation (in terms of the geomorphological context). Meanwhile, we have not yet found these sources.

\section{The other Pyrenean sources}

\subsection{Pyrenean Flysch flint}

The outcrops of Pyrenean Flysch flint also yielded an abundant and high quality siliceous material in the Montgaillard-Hibarette region (Barragué et al. 2001), as well as in the Bidache and Iholdy regions further west in the western Pyrenean zone (Tarriño 2007 and C. Normand archaeology field survey).

- the Montgaillard-Hibarette type. This name covers many aspects. Hibarette corresponds to the Paleolithic flaking workshops located at secondary procurement sources (Poudingues de Palassou), constituted in part by the dismantling of the Flysch limestones (Upper Cretaceaous); these latter outcrops are located at Montgaillard where flint nodules are found in their primary position (Barragué et al. 2001).

- Orignac flint was defined by S. Lacombe (1998) in the outcrops (Turonian to Santonian) located at the Adour Valley outlet. This flint is similar to that of MontgaillardHibarette but smaller in size (centimetric slabs). 


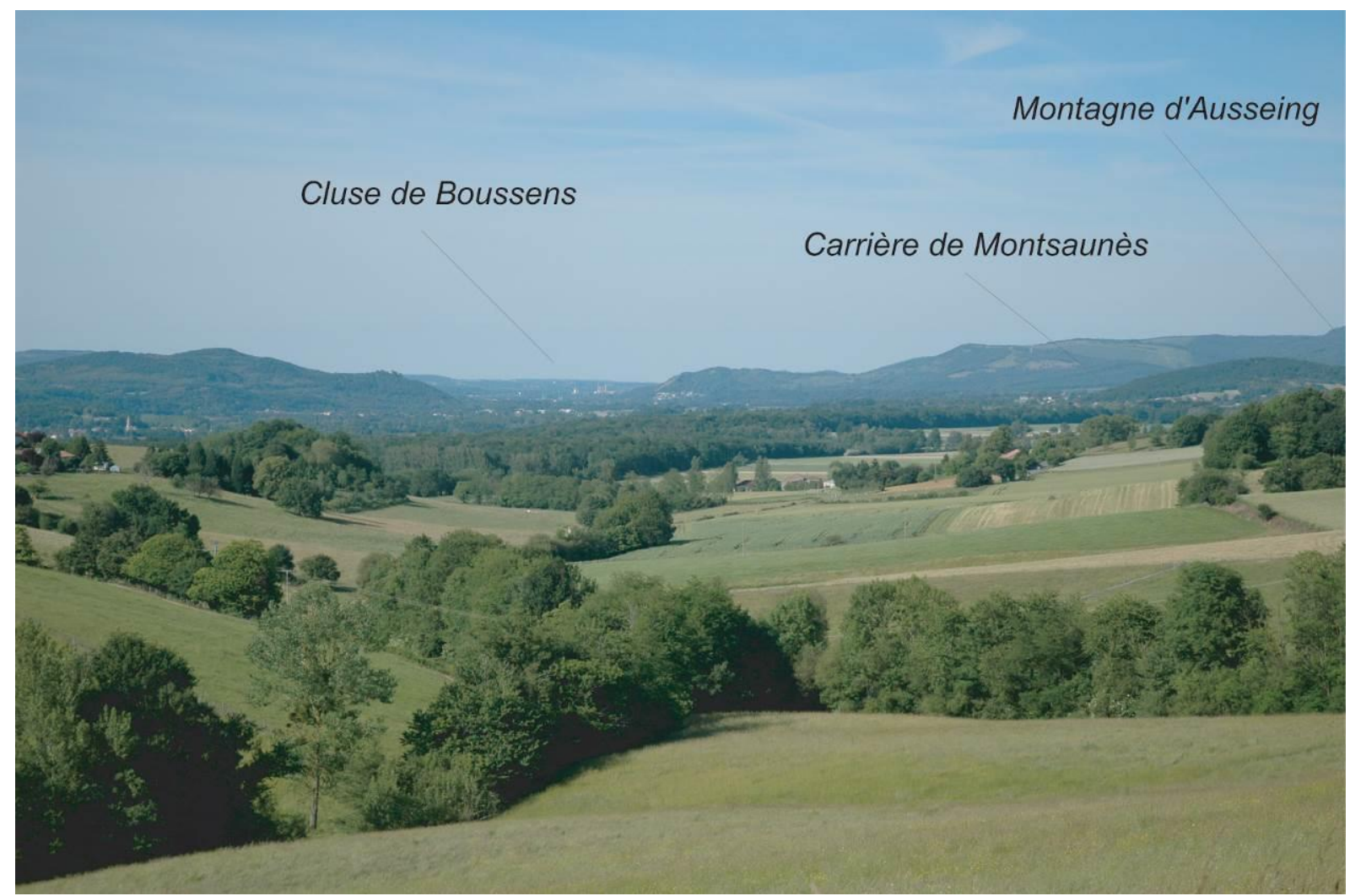

Figure 2. View from the $\mathrm{S}-\mathrm{W}$ of the Boussens Pass.

\subsection{Courensan flints}

This flint type, very similar to the Pyrenean "Blue" type, is located in the Gers department in the commune of Courrensan (Simonnet 1996). This zone was also surveyed by G. Duclos (1991), who discovered numerous Paleolithic surface sites.

\subsection{The sandstone sources of Armagnac}

Though it is found in the northern part of the Gers department, beyond the Pyrenean foothills zone, we can mention the siliceous sandstone of Cazalège (Castelnau d'Auzan). This is a very tough raw material, well adapted to flaking, that was mainly used during the Acheulean (Millet et al. 1999).

\subsection{Lepidorbitoide flints}

The important discoveries made in recent years most specifically concern one raw material type: Lepidorbitoides flints (Figures 3 to 5). This is a typical Pyrenean flint that does not exist in the Dordogne region. It was defined based on the work of Ch. Normand (1986), M. Séronie-Vivien (1994), and F. Bon et al. (1996). We formerly thought that this flint existed only in Chalosse, but it has also been identified in the Petites Pyrénées, in the Boussens water gap (Séronie-Vivien \& Foucher 2006), and other sources were recently discovered in the northern part of the Gers department (Colonge et al. 2011), as well as further south in the Adour basin (Séronie-Vivien et al. 2012).

These new data completely change the direction or orientation of the circulation of this material type and underline that the Pyrenean resource site context is not as simple as we thought just fifteen years ago. Now the discovery of a tool in Lepidorbitoide flint does not forcibly indicate that it came from Chalosse. 


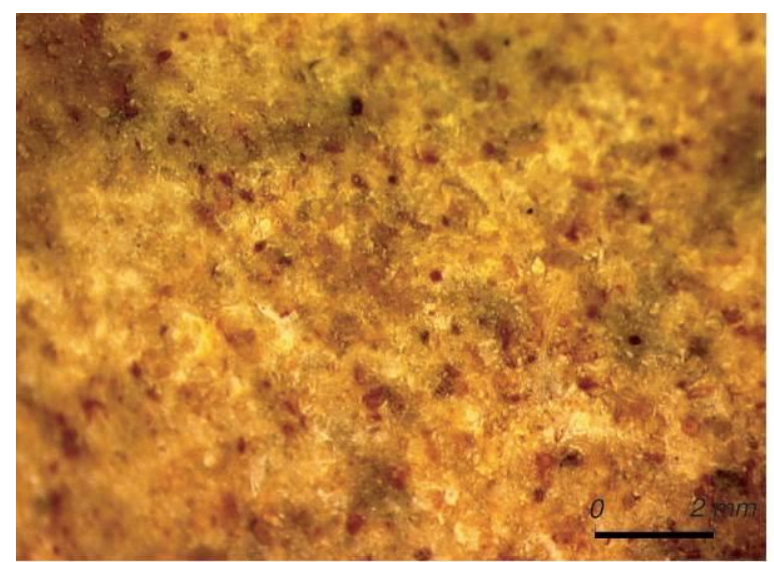

A : $T 20 e$

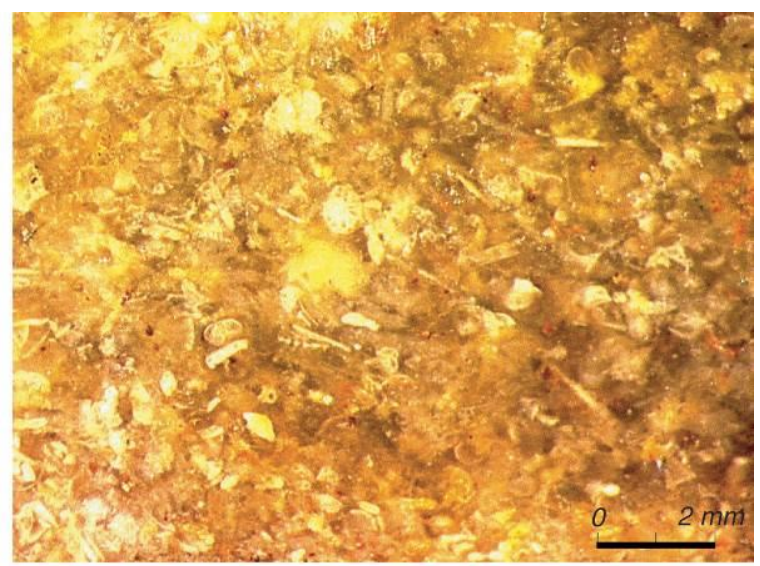

B : $M 305$

Figure 3. Textural types of the Tarté and Montsaunès flints. A ) Tarté type: wackestone texture with rounded intraclasts, often brownish, and lignitic fragments). B) Montsaunès type: packstone texture with rounded intraclasts and many bioclasts (ostrocods and small forams).

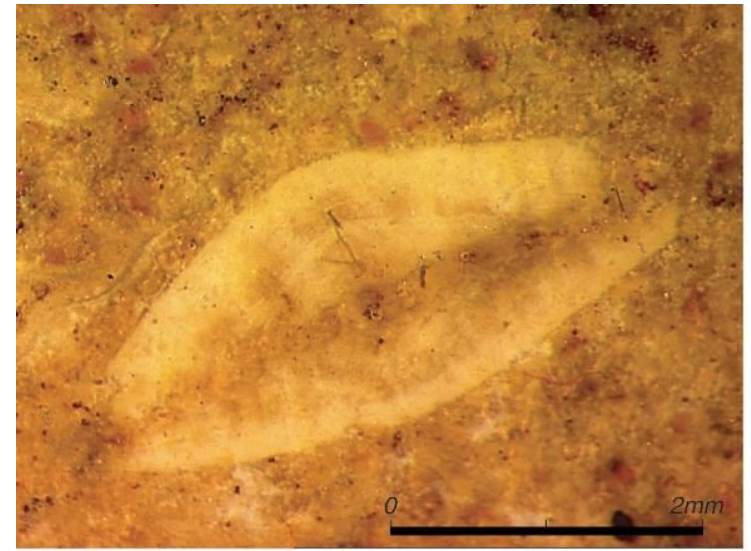

A : $T 94 C$

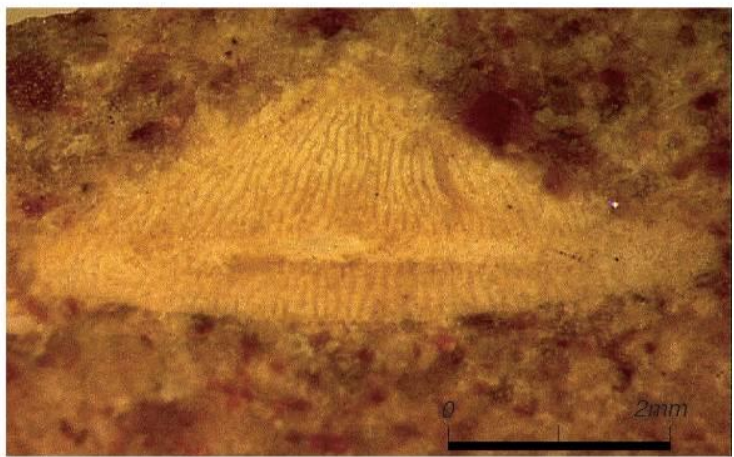

B : $T 70$

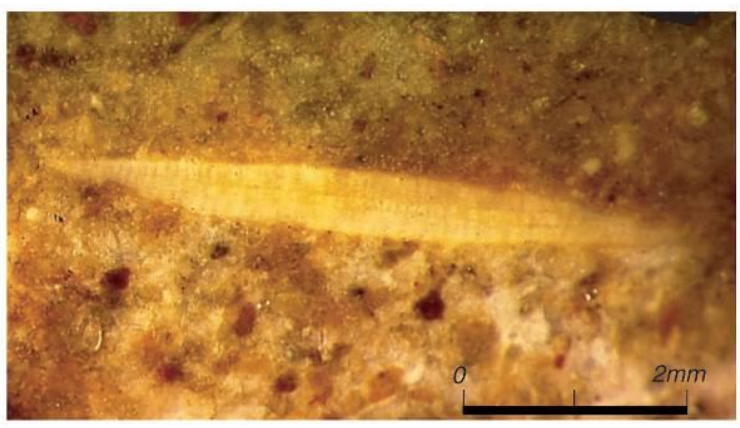

$D: T 20 d d$

Figure 4. Orbitoïdinés. A ) Orbitoides media (Tarté T94c). B ) Clypeorbis mamillata (Tarté T70). D ) Lepidorbitoides socialis (Tarté T20dd).

\section{Flints from the western and eastern Pyrenees}

In Chalosse, the Audignon-Montaut anticline and the Bastennes-Gaujac diapir are zones that are very rich in flint sites (alterites) and Paleolithic flaking workshops. Other more sparse sources are found at Tercis and Salies-du-Béarn (Tarriño 2007 and C. Normand archaeology field survey). 
In the western part of the Pyrenees, large sources were discovered and described in the Corbières and to the south of the Black Mountain (Briois 2005; Grégoire \& Bazile 2019; Grégoire et al. 2010).

We should also note that the large fluvial systems transported significant quantities of stone materials (flint and quartzites) and they were collected from the areas in which they were accessible during Prehistory, such as the Adour (all along its course from its exit from the foothills at Montgaillard) and the Garonne (in the Boussens water bank, at least until its confluence with the Tarn).

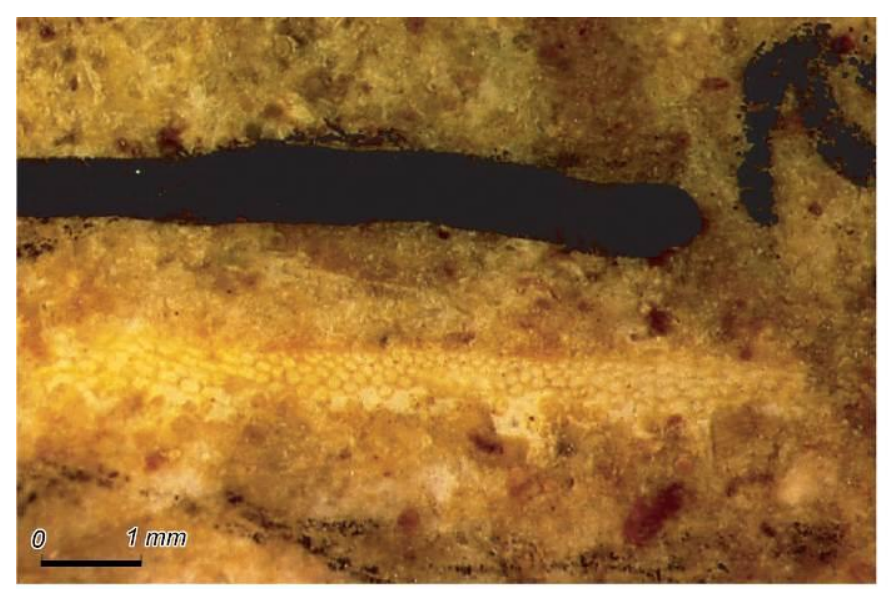

A : $T 20 b b$

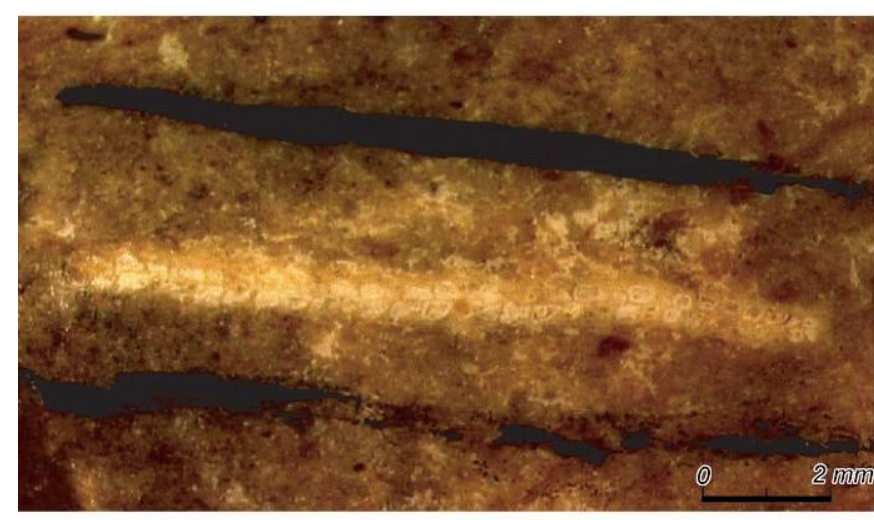

C: $T 81$

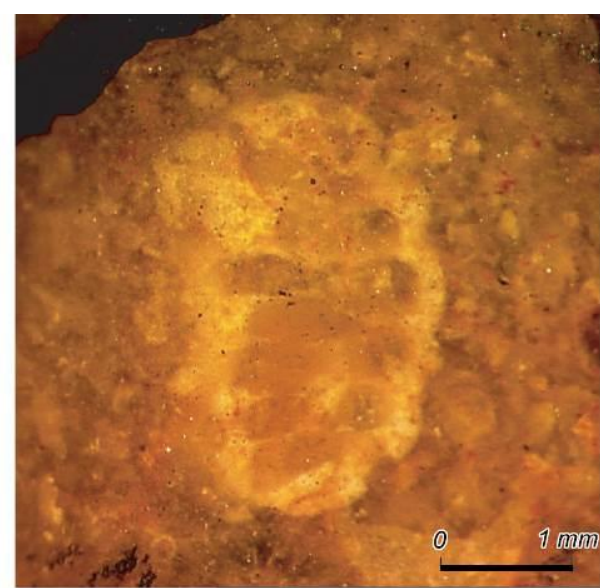

$B: T 19 b$

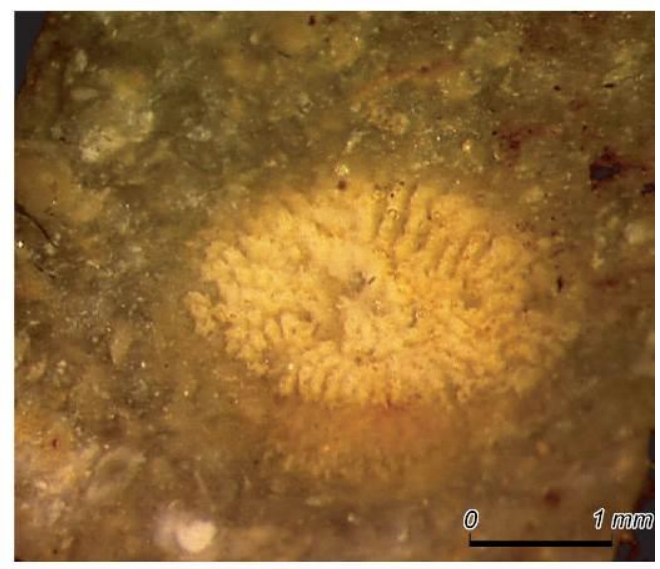

$D: T 19$

Figure 5. Algues: A) cf. Polygonella (possibly solénoporacée) Tarté T20bb. B) Neomerys (dasycladacée) Tarté T19b. C) Munieria (dasycladacée) Tarté T81. D) Neomerys (dasycladacée) Tarté T19.

\section{Flint beyond the Pyrenees}

These flints, qualified as allochthonous, are frequently found in Pyrenean sites throughout the Upper Paleolithic: Aurignacian, Gravettian, Solutrean and Magdalenian (Lacombe 1998; 2014; Bon 2002; Foucher 2004). They are very diverse and come mainly from the Quercy and Perigord regions: Verdier, Gavaudun, Fumelois, Belves, Gray-black Senonian from the Perigord region, Bergeracois, Jasperoids from the periphery of the Massif Central, or even the upper-basin of the Èbre (Tarriño 2006). The main studies of raw materials in the Perigord region are Séronie-Vivien \& Séronie-Vivien (1987), Morala \& Turq (1990), Demars (1994; 1998), Turq (2000). An analysis of Verdier flint is currently in progress (personal communications with Christian Servelle). 


\section{Flint economy in the Pyrenean Gravettian}

\subsection{Gargas Cave (Hautes-Pyrénées, France): a few reminders}

Gargas Cave is one of the reference sites for the European Gravettian due to its exceptional parietal art and its rich archaeological deposits. The latter were excavated from the end of the $19^{\text {th }}$ to the early $20^{\text {th }}$ centuries.

The most extensive excavations were realized by F. Régnault as early as 1873 , followed by É. Cartailhac and H. Breuil in 1911 and 1913, but the work of these latter researchers was not published until forty-five years later, based on their field notes and a synthetic typological study of the industries discovered (Breuil \& Cheynier 1958).

During the $20^{\text {th }}$ century, research in Gargas Cave was mainly focused on the parietal art (Foucher et al. 2007). The first painted handprints were discovered in 1906 by F. Régnault $(1907,1910)$ and a complete study of the hands and engraved panels was undertaken during the following years by $\mathrm{H}$. Breuil and É. Cartailhac, in collaboration with H. Obermaier (Cartailhac 1907; 1909; Cartailhac \& Breuil 1910; Breuil 1952; 1958). In 1976, C. Barrière published a very complete monograph on the parietal art and the engravings in particular, following an attempted synthesis by M. Cantet and A. Clot in 1974. Continuing the work of A. Sahly on the hands (1966), and that of A. Leroi-Gourhan (1967), in 1987 M. Groenen published a critical analysis with the first reasoned and completed inventory on this theme, until then treated in a very partial manner (Groenen 1987 ; 1988). A ${ }^{14} \mathrm{C}$ date of $26860 \mathrm{BP} \pm$ 460 , realized on a bone wedged into a fissure of the Great Hand Panel, established an indirect Gravettian framework for the parietal art (Clottes et al. 1992).

Since 2004, we have conducted a research program on this cave (Foucher et al. 2008; 2011; 2012; San Juan \& Foucher 2010). Our main aim is to obtain a detailed stratigraphic sequence of the site in order to define the succession of its occupations more precisely than was achieved by the synthetic scheme produced by the early excavators. It also provides an opportunity to conduct a paleo-environmental study of the site, which has never been done before. Since the stratigraphic sequence is thought to cover a broad chronological period (Mousterian, Chatelperronian, Aurignacian and Gravettian), this study will be the first of its kind in the Pyrenees.

This new field research also takes a broader, more global approach to the site, including a revision of the early Cartailhac-Breuil collections and an integration of both its decorated cave and habitation site aspects, with the goal of obtaining a better understanding of the functional, spatial and chronological features of its occupation by the authors of the parietal art. Through this research, we hope to integrate an ensemble of reliable chrono-cultural elements that will enable us to better situate the occupations and art of Gargas within the regional and European contexts.

\subsection{The Pyrenean Gravettian lithic industries: typo-technological data}

The data on the lithic industries of Gargas Cave are part of the more general data set associated with the Pyrenean Gravettian. We have already presented a first synthesis that included the results obtained from a revision of the early Cartailhac-Breuil collections (Foucher 2004). The data collected through the new excavations with contribute more precise information, but will probably not change the general scheme defined some fifteen years ago.

The main elements of the synthesis that we presented at the colloquium in Les Eyzies (France) remain current (Foucher et al. 2008a). What we observe is a high degree of homogeneity in the Gravettian lithic industries of the Atlantic and central Pyrenees, characterized by:

- Noailles burins (dominant), 
- backed pieces (Gravette and Vachons points, and microgravettes),

- scaled pieces (pièces esquillées).

These three typological groups dominate in the lithic assemblages of all the Pyrenean sites (Foucher 2004). They are followed by backed blades and bladelets, bladelets with marginal retouch, truncations on blades or bladelets, and then endscrapers, truncated and dihedral burins. We also observe that the tools are very small (microlithism), as much among the Noailles burins as the Gravette points (microgravettes), and the bladelets with marginal retouch (Figure 6).

The absence of Font-Robert points is another characteristic typological feature of these assemblages: they paradoxically appear much further west at the sites of Irikaitz (País Vasco), Cueva Morín (Cantabria) and La Viña (Asturias), as well as in the Pyrenean hinterland to the north at the Les Battuts rock shelter (Tarn), even if their presence there is almost anecdotal. The recent discovery of an open-air site near Bayonne (Le Prissé) that yielded one FontRobert point (personal communication Marina Redondo) barely modifies the general context. We must await the publication of this site, as well as that of Viña (and revise the data from Cueva Morín), and then reevaluate the possible relationships with Irikaitz in order to understand the significance of this typological component that seems to be more localized on the Cantabrian Cornice.

Minor statistical variations exist between the sites, but they do not seem to indicate a chronological evolution (Foucher 2004); they could as well be due to factors other than cultural ones (frequent biases in statistical calculations due to selective sorting by some early excavators), or functional variability ("specialized" sites). In any event, the lithic assemblages from sites excavated long ago (Isturitz, Gargas, Tarté), and others more recently (Enlène), show great similarities in both the general composition of their tool assemblages and in the forms and manufacturing techniques of some pieces (Gravette points, Noailles burns, scaled pieces). This is even more evident if we consider the variables forcibly introduced by the heterogeneity of the occupations and the possible functional differences of the sites.

The new data concern the chrono-cultural attribution of the shouldered points at Brassempouy. The context of their discovery by E. Piette being too vague, later attempts to attribute them hesitated between the Gravettian and Solutrean (Delporte 1968; Foucher 2004: 139-143). The discovery of new points in stratigraphic position during the excavations by $\mathrm{H}$. Delporte (sector GG2) permitted their attribution to the Gravettian (Goutas \& Simonet 2009). In addition, in his work at Isturitz, Aurélien Simonet defined a particular point type with an angled back, present only at the top of the Gravettian sequence (Simonet 2009).

From a technological point of view, the techniques for manufacturing blades and bladelets were relatively simple (both unidirectional and bidirectional laminar flaking, continuity from blade to bladelet detachment). A systematic analysis of the butts of the blanks detached indicates the use of soft stone hammer percussion (a large proportion of highly abraded, or even polished, butts). There was also an autonomous production of flakes and elongated flakes (Isturitz, Enlène, Gargas). There seems to have been little selection of raw materials according to the tool types to be manufactured (Foucher 2004; Simonet 2009). We can note just the one counter example of the shouldered points at Brassempouy, made exclusively from Chalosse flint (Goutas \& Simonet 2009). The quality of the siliceous materials from the Pyrenees nonetheless had an influence on the size of the laminar blanks. Due to the dimensions of the nodules available in the central Pyrenean sites, in this zone (Gargas, Enlène), only small blades and bladelets could be manufactured; to find productions of larger blanks, one must move closer to the Chalosse and Flysch flint sources (Isturitz, Brassempouy, Tercis). 

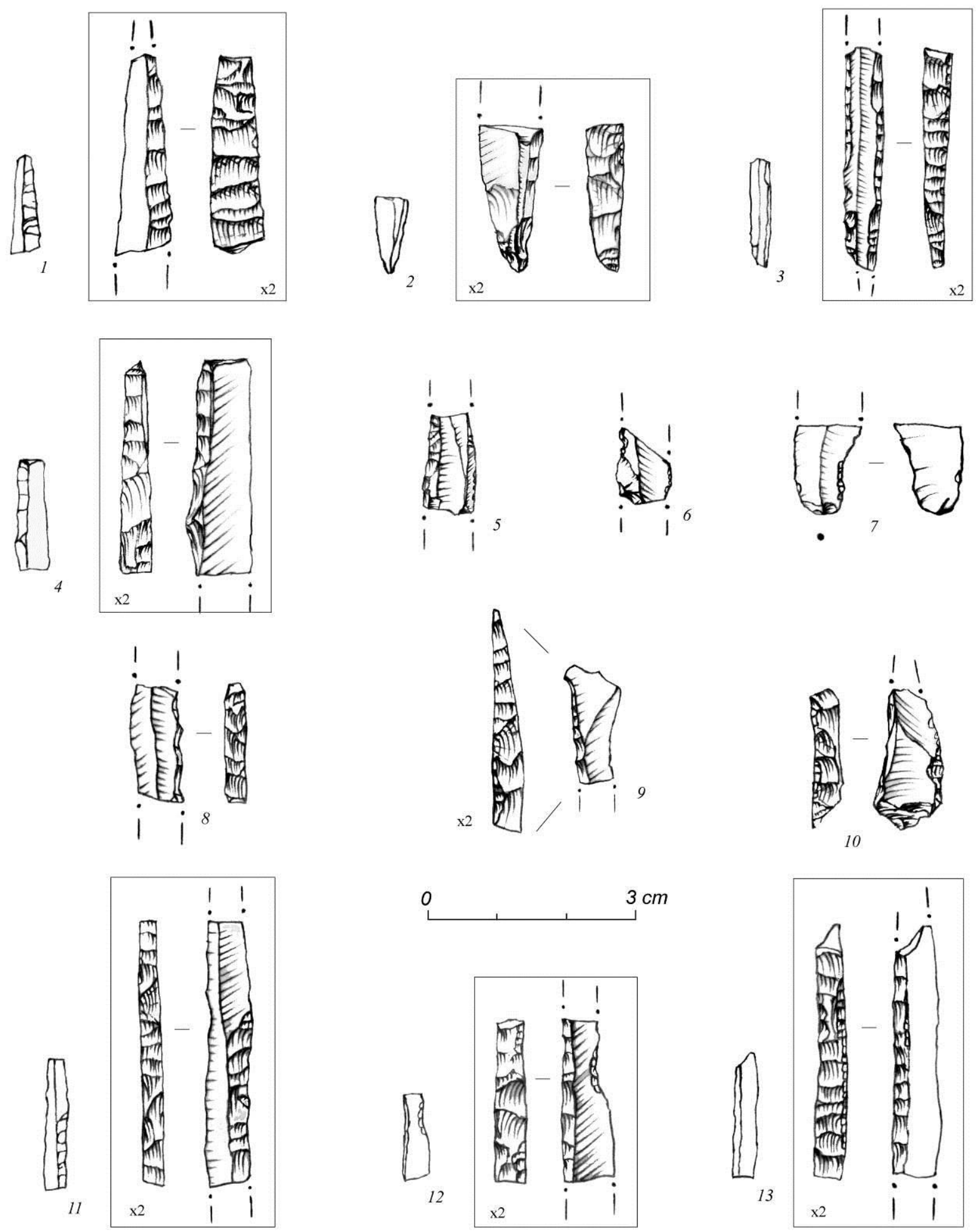

Figure 6. Microgravettes and micro backed bladelets of Gargas Gravettian.

In any event, it is not yet possible to refine the chrono-cultural framework or to imagine the existence of "sub-facies" based on technological data alone (Simonet 2009).

It is also worth noting that in the central and western Pyrenees, we do not find the other industrial entities or technical procedures defined in the Perigord, such as Flechettes, FontRobert points, the procedures associated with Raysse burins, etc., considered as markers of chrono-cultural trends in the Gravettian. 


\subsection{The Pyrenean radio-chronological framework}

For information on the Pyrenean radio-chronological framework, we recommend several articles (Foucher et al. 2011; Foucher 2013).

For the Gravettian occupations at Gargas, the results suggest long term occupations of the cave (3000 years), with a period of more intense occupation from 27,000 - 25,000 BP. From a chrono-cultural point of view, we observe an early phase with Noailles burins, during the 28,000 - 27,000 BP interval and a middle phase with an identical facies, between 27,000 and $25,000 \mathrm{BP}$.

\subsection{Siliceous raw material circulation: economic data}

The map of Figure 7 illustrates the preliminary results obtained at Gargas on the siliceous raw materials used in the lithic industry. The percentages mentioned are calculated based on the tool assemblage.

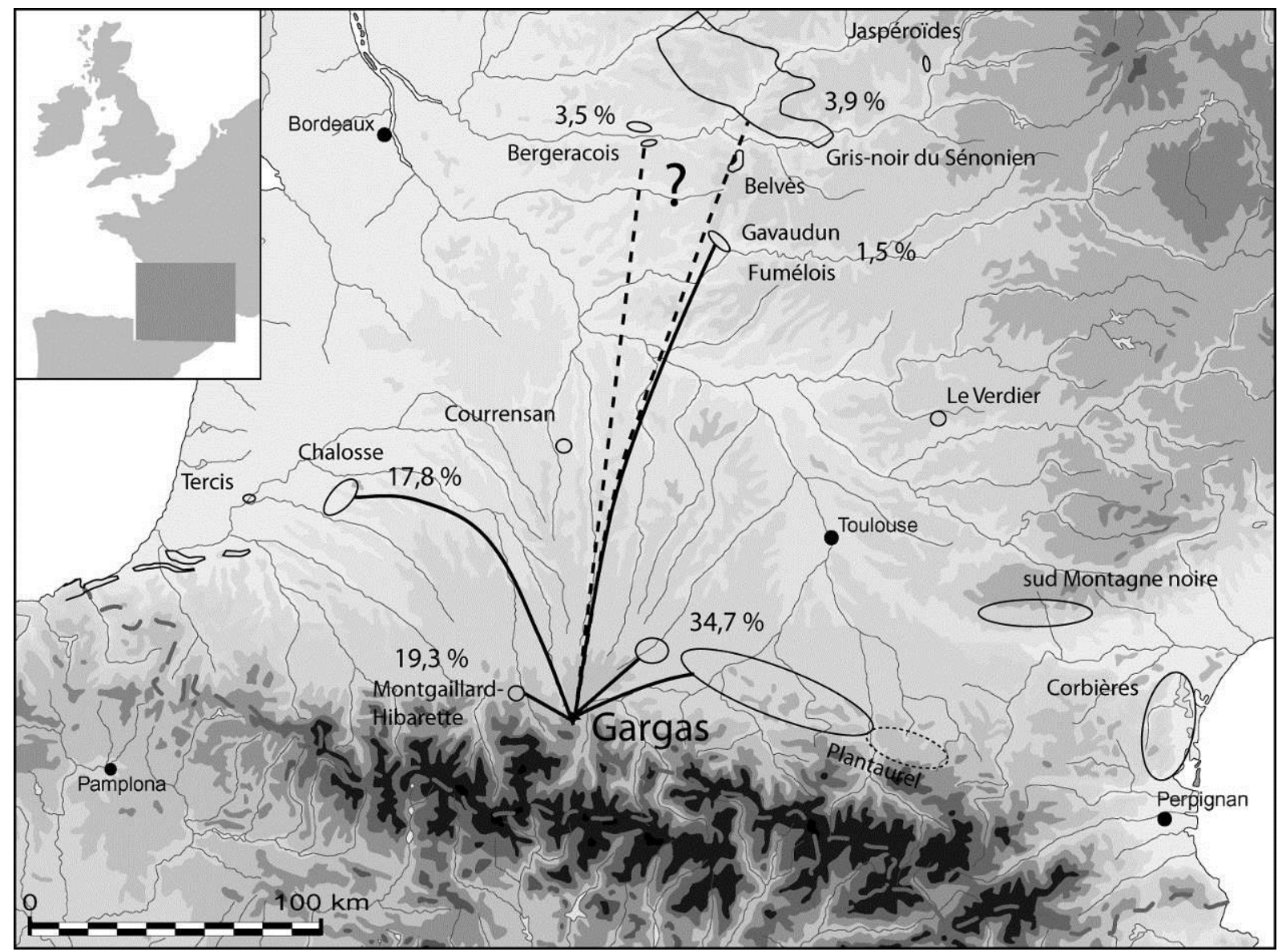

Figure 7. Map of siliceous raw materials used in the lithic industry at Gargas Gravettian (Cartailhac-Breuil collections).

The flint of the Petites Pyrénées is dominant (34.7\%), followed by Flysch flint (including Hibarette: $19.3 \%$ ) and lepidorbitoides $(17.8 \%)$. Gargas is thus unusual in that it is a Pyrenean occupation site located relatively far from the local raw material sources $(20-40 \mathrm{~km})$; the closest ones are $24 \mathrm{~km}$ to the north (Lespugue-Montmaurin- Blajan sources) and the FlyschHibarette sources $42 \mathrm{~km}$ to the west-north-west. We should note the high proportion of flint with lepidorbitoides (17.8\%) whose precise provenience remains to be determined (Chalosse or Adour-Gélise basin or Cluse de Boussens). There are several flint types (7.4\%) whose origin in the Perigord region remains to be verified. On the other hand, Fumelois and 
Gavaudun flint is clearly present (1.5\%). These latter could appear anecdotal, but are significant in the orientation of the north-south movements of Gravettian people. Finally, there is one allochthonous flint that could come from the Èbre valley basin (personal communication A. Tarriño).

Given our current knowledge of the raw materials used by Gravettian people, we can reasonably assume that flint procurement was not very difficult in the Pyrenees. Though there are gaps in the distribution of siliceous resources (Figure 1), those available cover the entire Pyrenean zone and could provide prehistoric peoples with abundant and high quality materials.

This specific context nonetheless implies that the Gravettians developed different procurement strategies depending on where they were, including actions to anticipate their future needs. On one hand, we can distinguish an economy of abundance in proximity to the large Chalosse and Flysch flint sources, and on the other, a more rational economy in the Petites Pyrénées zone, where raw materials were more scarce and more heterogeneous in quality This local economy is accompanied by the procurement of more long distance flints (example of Gargas: Figure 7).

A few broad socio-economic traits can be deduced from all of these data:

- constant contacts and exchanges among Gravettian groups in the Pyrenees, in a geographic zone covering at least the Greater-South-West of France; it is possible that this was facilitated by certain very mobile individuals specialized in the prospection of siliceous materials;

- two large north-south and west-east circulation axes in the Atlantic river basin, probably periodically followed in both directions. We also observe these movement directions in other materials, such as shells (San Juan-Foucher, Foucher 2010; San Juan-Foucher 2011; 2013).

\section{Acknowledgment}

Thanks to Magen O'Farrell for the English translation.

\section{References}

Barragué, J., Barragué, É., Jarry, M., Foucher, P. \& Simonnet, R. 2001, Le silex du flysch de Montgaillard et son exploitation sur les ateliers du Paléolithique supérieur à Hibarette (Hautes-Pyrénées). PALEO. Revue d'archéologie préhistorique, 13: 29-52. (in French) ("The flint of the Montgaillard flysch and its production on the Upper Palaeolithic workshops in Hibarette (Hautes-Pyrénées)") URL: http://paleo.revues.org/951

Bon, F. 2002, L'Aurignacien entre mer et océan : réflexion sur l'unité des phases anciennes de l'Aurignacien dans le Sud de la France. Mémoires de la Société préhistorique française Vol. 29. Société préhistorique française, Paris, 253 p. (in French) ("The Aurignacian between sea and ocean: reflection on the unity of the ancient phases of the Aurignacian in the South of France")

Bon, F., Simonnet, R., \& Vézian, J. 2005, L'équipement lithique des Aurignaciens à la Tuto de Camalhot (Saint-Jean-de-Verges, Ariège), sa relation avec la mobilité des groupes et la répartition de leurs activités dans un territoire. In: Territoires, déplacements, mobilité, échanges durant la Préhistoire. Actes du 126e Congrès National des Sociétés Historiques et Scientifiques. Toulouse, 2001 (Jaubert, J. \& Barbaza, M., Eds.). CTHS, Paris: 173-184. (in French) ("The lithic equipment of the Aurignacians at Tuto de 
Camalhot (Saint-Jean-de-Verges, Ariege), its relationship with the mobility of the groups and the distribution of their activities within a territory")

Bon, F., Chauvaud, D., Dartiguepeyrou, S., Gardère, Ph., \& Mensan R. 1996, La caractérisation du silex de Chalosse. Antiquités nationales, 28: 33-38 (in French) (The Characterisation of the Chalosse flint)

Breuil, H. 1952, Quatre cents siècles d'art pariétal. Les cavernes ornées de l'Age du Renne. Éditions Windels, Montignac. 418 p. (in French) ("Four hundred centuries of cave art. The decorated caves from the Age of the Reindeer")

Breuil, H., \& Cheynier, A. 1958, Les fouilles de Breuil et Cartailhac dans la grotte de Gargas en 1911 et 1913. Bulletin de la Société méridionale de Spéléologie et de Préhistoire, 5(1954-55): 341-382 (extrait du Bulletin de la Société d'Histoire naturelle de Toulouse, 1958, 93) (in French) ("The excavations of Breuil and Cartailhac from the Gargas Cave, in 1911 and 1913")

Briois, F. 2000, Lithothèque des matières premières siliceuses. Bulletin scientifique de la région Midi-Pyrénées 1999, Service régional de l'archéologie, Toulouse: 224-225. (in French) ("Siliceous raw materials lithotheque")

Briois, F. 2005, Les industries de pierre taillée néolithiques en Languedoc occidental. Nature et évolution des outillages entre les $6^{e}$ et $3^{e}$ millénaires av. J.-C. : Association pour le développement de l'archéologie en Languedoc-Roussillon (Monographies d'Archéologie Méditerranéenne, Vol. 20), Lattes, 341 p. (in French) ("The Neolithic chipped stone industries in Western Languedoc. The nature and evolution of tools between the 6th and 3rd centuries BC")

Briois, F., Chalard, P., Lacombe, S., Servelle, C., Simonnet, R. 1997, Lithothèque régionale. Bulletin scientifique de la région Midi-Pyrénées 1996, Service régional de l'archéologie, Toulouse: 227-228. (in French) "Regional lithotheque")

Cartailhac, É. 1907, Les mains rouges et noires de la grotte de Gargas. In: Congrès de l'AFAS, II, Lyon: 717-720. (in French) ("The red and black hands from the Gargas cave")

Cartailhac, É. 1906-1909, Les mains rouges et noires et les dessins paléolithiques de la grotte de Gargas. Bulletin de la Société d'archéologie du Midi de la France, 37: 140-141. (in French) ("The red and black hands and the Palaeolithic paintings from the Gargas cave")

Cartailhac, É., \& Breuil, H. 1910, Les peintures et gravures murales des cavernes pyrénéennes, IV Gargas, commune d'Aventignan (Hautes-Pyrénées). L'Anthropologie, 21: 129-148. (in French) ("The paintings and wall engravings of the Pyrenean caves, IV Gargas, Aventignan commune (Hautes-Pyrénées)")

Clottes, J., Valladas, H., Cachier, H., \& Arnold, M., . 1992, Des dates pour Niaux et Gargas. Bulletin de la Société Préhistorique Française: 270-274. (in French) ("Dates for Niaux and Gargas") doi:10.3406/bspf.1992.9532

Colonge, D., Chalard, P., Billote, M., Ducasse, S., \& Platel, J.-P. 2011, Nouvelle découverte d'un gîte à silex à Lépidorbitoïdes dans le Sud-Ouest de la France (Saint-Aubin, Gers) et implications archéologiques. Bulletin de la Société Préhistorique Française, 108(3): 561-564. (in French) ("New discovery of a flint deposit in Lépidorbitoïdes in the South West of France (Saint-Aubin, Gers) and archaeological implications") 
Delporte, H. 1968, Brassempouy: ses industries d'après la collection Piette. Zephyrus, 18(1967): 5-41. (in French) ("Brassempouy: Its industries from the Piette collection")

Demars, P.-Y. 1994, L'économie du silex au Paléolithique supérieur dans le nord de l'Aquitaine. Thèse de Doctorat d'État, Université de Bordeaux I., 2 vol., 819 p. (in French) ("Flint economy of Upper Palaeolithic in northern Aquitaine")

Demars, P.-Y. 1998, Circulation des silex dans le nord de l'Aquitaine au Paléolithique supérieur. L'occupation de l'espace par les derniers chasseurs-cueilleurs. Gallia Préhistoire, 40: 1-28. (in French) ("The circulation of flint in the northern Aquitaine in Upper Palaeolithic. The occupation of space by the last hunter-gatherers") doi:10.3406/galip.1998.2156

Duclos, G. 1991, Eauze de mémoire d'hommes et de pierres. In: Eauze, Terre d'histoire, Conseil général du Gers, Auch. p. 21-43. (in French) ("Eauze from the memory of people and stones")

Fernandes, P., Raynal, J.-P., Tallet, P., Tuffery, Ch., Piboule, M., Séronie-Vivien, M.-R., Séronie-Vivien, M., Turq, A., Morala, A., Affolter, J., Millet, D., Millet, F.,. Bazile, F., Schmidt, P., Foucher, P., Delvigne, V., Liagre, J., Gaillot, S., Morin, A., Moncel, M.-H., Garnier, J.-F., \& Léandri-Bressy C. 2013, Une carte et une base de données pour les formations à silex dans le Sud de la France : un outil pour la pétroarchéologie. PALEO. Revue d'archéologie préhistorique, 24: 219-228. (in French) ("A map and a database for flint bearing formations in Southern France: a tool for Petroarchaeology") URL: http://paleo.revues.org/2633

Foucher, P. 2004, Les industries lithiques du complexe Gravettien-Solutréen dans les Pyrénées. Techno-typologie et circulation des matières siliceuses de part et d'autre de l'axe Pyrénées-Cantabres. Thèse de doctorat, Université de Toulouse 2-le Mirail, 647 p. (in French) ("The lithic industries of the Gravettian-Solutrean complex in the Pyrenees. Techno-typology and circulation of raw materials on both sides of the PyreneanCantabrian Moutains")

Foucher, P. 2006, Gargas et l'Atlantique : les relations transpyrénéennes au cours du Gravettien. Munibe. 2005-2006, 57, tome II : Arqueología, Homenaje al Prof. Jesús Altuna: 131-147. (in French) ("Gargas and the Atlantic: the trans-Pyrenne relations during the Gravettian") URL: http://hal.archives-ouvertes.fr/hal-00464645/fr/

Foucher, P. 2007, Les territoires solutréens des Pyrénées-Cantabres, d'après les armatures foliacées et la circulation des matières premières, In: Fronteras naturales y fronteras culturales en los Pirineos prehistóricos, Actas de la reunión de Tarascon-sur-Ariège, mars 2004, (Cazals, N., González Urquijo, J., Terradas, X. Eds.) PUbliCan-Ediciones de la Universidad de Cantabria, Santander, p. 279-299. (in French) ("The Solutreen territories from the Cantabrian Pyrenees, from the foliaceous armatures and the circulation of the raw materials") URL: http://hal.archives-ouvertes.fr/hal-00834408

Foucher P. 2013, Synthèse chrono-culturelle sur le Gravettien des Pyrénées: constat et réflexions sur la stabilité régionale des traditions techniques. In: Pensando el Gravetiense : nuevos datos para la región cantábrica en su contexto peninsular y pirenaico / Rethinking the Gravettian: new approaches for the Cantabrian Region in its peninsular and pyrenean contexts, , Actas del coloquio de Altamira, 20-22 de octubre 2011 (de las Heras, C., Lasheras, J.-A., Arrizabalaga, A., de la Rasilla, M., Eds.), Monografías del Museo Nacional y Centro de Investigación de Altamira, Vol. 23, Madrid: p. 142-160. (in French) ("Chrono-cultural synthesis of the Gravettian in the 
Pyrenees: observation and reflection on the regional stability of technical traditions") URL: http://museodealtamira.mcu.es/web/docs/PrehistoriayArte/MdA_Gravetiense_can tabrico.pdf

Foucher, P., San Juan-Foucher, C. 2008, Du silex, de l'os et des coquillages : matières et espaces géographiques dans le Gravettien pyrénéen. In: Space and Time: Which Diachronies, Which Synchronies, Which Scales? I Sections C64 et C65. Typology vs. Technology. Actes du XVe Congrès Mondial de l'Union Internationale des Sciences Préhistoriques et Protohistoriques (UISPP) de Lisbonne-2006, Vol. 21, (Aubry, Th., Almeida, F., Araújo, A.-C., Tiffagom, M. Eds.). BAR International Series Vol. 1831, Archaeopress, Oxford: p. 45-55. (in French) ("Of flint, bone and shells: Materials and geographical areas in the Pyrenean Gravettien") URL: http://hal.archivesouvertes.fr/hal-00494322/fr/

Foucher, P., San Juan-Foucher, C., Rumeau, Y. 2007, La grotte de Gargas. Un siècle de recherches. Édition Communauté de communes du canton de Saint-Laurent-de-Neste, Saint-Laurent-de-Neste, 126 p. (in French) ("The Gargas cave. A century of research")

Foucher, P., San Juan, C., Sacchi, D., Arrizabalaga, A. 2008a, Le Gravettien des Pyrénées. In: PALEO. Revue d'archéologie préhistorique, 20. Le Gravettien: entités régionales d'une paléoculture européenne. Actes de la table ronde des Eyzies-de-Tayac, juillet 2004: 331-356. (in French) ("The Gravettian of the Pyrenees") URL: http://paleo.revues.org/1604

Foucher, P. San Juan-Foucher, C., Ferrier, C., Couchoud I., Vercoutère, C. 2008b, La grotte de Gargas (Aventignan, Hautes-Pyrénées): nouvelles perspectives de recherche et premiers résultats sur les occupations gravettiennes. In: Les sociétés du Paléolithique dans un grand sud-ouest de la France: nouveaux gisements, nouveaux résultats, nouvelles méthode, (Jaubert, J., Bordes, J.-G., Ortega, I. Eds.), Journées SPF, Université de Bordeaux I-Talence, 2006, Éd. Société préhistorique française (Mémoire 47), Paris: p. 301-324. (in French) ("The Gargas Cave (Aventignan, Hautes-Pyrénées): new research perspectives and first results on the Gravettian occupations") URL: http://hal.archives-ouvertes.fr/hal-00494329/fr/

Foucher, P., San Juan-Foucher, C., Oberlin, C. 2011, Les niveaux d'occupation gravettiens de Gargas (Hautes-Pyrénées): nouvelles données chronostratigraphiques. In: À la recherche des identités gravettiennes : actualités, questionnements et perspectives, Actes de la table ronde sur le Gravettien en France et dans les pays limitrophes, Aix-enProvence, 6-8 octobre 2008 (Goutas, N., Klaric, L., Pesesse, D., Guillermin, P. Eds), Mémoire Vol. 52, Éd. Société préhistorique française, Joué-lès-Tours, p. 373-385. (in French) ("The Gravettian occupation layers of Gargas (Hautes-Pyrenees): New chronostratigraphic data ") URL: http://hal.archives-ouvertes.fr/hal-00831740

Foucher, P., San Juan-Foucher, C., Vercoutère, C., Ferrier, C. 2012, La grotte de Gargas (Hautes-Pyrénées, France): l'apport du contexte archéologique à l'interprétation de l'art pariétal. Préhistoire, Art et Sociétés, Bulletin de la Société Préhistorique AriègePyrénées, 65-66(2010-2011). Special issue: L'art pléistocène dans le monde / Pleistocene art of the world / Arte pleistoceno en el mundo, Actes du Congrès IFRAO, Tarascon-sur-Ariège, 6-11 septembre 2010: 52-53 et CD: p. 209-225. (in French) ("The Gargas cave (Hautes-Pyrénées, France): The contribution of the archaeological context in the interpretation of parietal art") URL: http://hal.archives-ouvertes.fr/hal-00831795

Goutas, N., Simonet, A. 2009, Le secteur GG2 de la grotte du Pape à Brassempouy (Landes): un dépôt intentionnel d'armes gravettiennes? Bulletin de la Société Préhistorique 
Française. 106(2): 257-291. (in French) ("The GG2 sector of the Pape à Brassempouy cave (Landes): an intentional deposit of Gravettian weapons?") Stable URL: http://www.jstor.org/stable/23240607

Grégoire, S., Bazile, F. 2009, La lithothèque matières premières siliceuses en LanguedocRoussillon. Un outil pour la reconstitution des territoires. In: Els Pirineus i les àrees circumdants durant el Tardiglacial. Mutacions i filiacions tecnoculturals, evolució paleoambiental (16000-10000 BP). Homenatge al professor Georges Laplace. XIV colloqui internacional d'arqueologia de Puigcerdà 10-12 de noviembre de 2006 (Fullola, J.-M., Valdeyron, N., Langlais, M. Eds.) Institut d'Estudis Ceretans, Puigcerdà: p. 227-238. (in French) ("The lithotheque of siliceous raw materials in Languedoc-Roussillon. A tool for the reconstruction of territories")

Grégoire, S., Bazile, F., Boccaccio, G., Menras, C., Pois, V., Saos, T. 2010, Les ressources siliceuses en Languedoc-Roussillon. Bilan des données acquises. In: Silex et territoire préhistoriques. Avancées des recherches dans le Midi de la France, Actes de la table ronde de Lattes, juin 2008, (Bressy, C., Grégoire, S., Bazile, F., Eds.) Les C@ hiers de Géopré, Vol. 1, Géopré, Paris: 12-18. (in French) ("The siliceous resources in Languedoc-Roussillon. Evaluation of acquired data")

Groenen, M. 1987, Les représentations des mains négatives dans les grottes de Gargas et de Tibiran (Hautes-Pyrénées). Approche méthodologique. Mémoire présenté en vue de l'obtention du grade de Licencié en Histoire de l'Art et Archéologie, Université libre de Bruxelles, Faculté de Philosophie et Lettres, 2 vol. , Bruxelles, 214 p., 60 pl., 6 tab. (in French) ("The representations of hands in negative in the caves of Gargas and Tibiran (Hautes-Pyrénées). Methodological approach")

Groenen, M. 1988, Les représentations de mains négatives dans les grottes de Gargas et de Tibiran (Hautes-Pyrénées). Approche méthodologique. Bulletin de la Société royale belge d'Anthropologie et de Préhistoire, 99: 81-113. (in French) ("The representations of hands in negative in the caves of Gargas and Tibiran (Hautes-Pyrénées). Methodological approach")

Lacombe, S. 1998, Préhistoire des groupes culturels au Tardiglaciaire dans les Pyrénées centrales. Apports de la technologie lithique. Thèse de doctorat, Université de Toulouse-le-Mirail, 385 p. 100 fig. (in French) ("The prehistory of cultural groups in the Late Glacial in the central Pyrenees. Contributions of lithic technology")

Lacombe, S. 1999, Stratégies d'approvisionnement en silex au Tardiglaciaire. L'exemple des Pyrénées centrales françaises. Préhistoire ariégeoise, Bulletin de la Société préhistorique Ariège-Pyrénées, 1998, 53: 223-266. (in French) ("Flint procurement strategies in the Late Glacial. The example from the French Central Pyrenees")

Lacombe, S. 2014, Ce que révèlent les silex sur les fréquentations humaines. In: La caverne des Trois-Frères. Anthologie d'un exceptionnel sanctuaire préhistorique, (Bégouën, R., Clottes, J., Feruglio, V. \& Pastoors, A. Eds.), Association Louis Bégouën, Somogy Éditions d'art, Paris : p. 223-225. (in French) ("What flint reveals about human visitations")

Leroi-Gourhan, A. 1967, Les mains de Gargas. Essai pour une étude d'ensemble, Bulletin de la Société préhistorique française, 64, p. 107-122. (in French) ("The hands of Gargas. Essay for a comprehensive study")

Leymerie, A.1881, Description géologique et paléontologique des Pyrénées de la HauteGaronne. Carte topographique et géologique à l'échelle de 1/200000 et atlas, Privat, 
Toulouse. (in French) ("The geologic and paleontological description of the Pyrenees in the Haute-Garonne: Topographic and geologic map at 1/200000 scale and atlas")

Méroc, L. 1947, Le silex dans le bassin sous-pyrénéen de la Garonne et son emploi par l'homme préhistorique. Bulletin de la Société archéologique du Midi de la France, 3e série, 5: 234-250. (in French) ("The flint in the sub-Pyrenean basin of the Garonne and its use by prehistoric man")

Méroc, L. 1953, La conquête des Pyrénées par l'Homme. Premier Congrès International de Spéléologie, Paris, Tome IV, Section 5: 33-51. (in French) ("The conquest of the Pyrenees by Man ")

Millet, D., Jaubert, J., Duclos, G., Capdeville, J.-P. \& Al. 1999, Une exploitation paléolithique de grès en Armagnac: le site de Cazalège à Castelnau d'Auzan (Gers). PALEO. Revue d'archéologie préhistorique, 11: 43-70. (in French) ("A Palaeolithic Workshop of Sandstone in Armagnac : the site of (Castelnau-d'Auzan, Gers, S.-W. France") doi:10.3406/pal.1999.1170

Morala, A., Turq, A. 1990, Les stratégies d'exploitation du milieu minéral, du Riss à l'Holocène, en Haut-Agenais (Sud-Ouest de la France). In: Le silex de sa genèse à l'outil. Actes du $V^{e}$ Colloque international sur le Silex (Vth International Flint Symposium) Bordeaux, 17 sept.-2 oct. 1987. (Séronie-Vivien, M.-R., Lenoir, M., Eds.), Cahiers du Quaternaire Vol. 17, Editions du Centre national de la recherche scientifique, Paris, p. 405-414. (in French) ("The strategies of minerals exploitaion, from Riss to Holocene, in Haut-Agenais (South-West of France)")

Normand, C. 1986, Inventaire des gîtes à silex de la Chalosse (1984-1985). Bulletin de la Société de Borda. 402: 133-140. (in French) ("The inventory of the flint deposits from Chalosse (1984-1985)")

Régnault, F. 1907, Empreintes de mains humaines dans la grotte de Gargas (HautesPyrénées). In: Comptes Rendus de l'Association Française pour l'Avancement des Sciences, $35^{e}$ session, Lyon 1906, Part 2, Secrétariat de 1'A.F.A.S, Paris: p. 720-722. (in French) ("Human handprints in the Gargas cave (Hautes-Pyrénées)")

Régnault, F. 1910, Empreintes de mains humaines dans la grotte de Gargas (Hautes-Pyrénées. Bulletins et Mémoires de la Société d'Anthropologie de Paris, 7, Ve série, C.R. du 5 juillet 1906, p. 331-332. (in French) ("Human handprints in the Gargas cave (HautesPyrénées)") doi:10.3406/bmsap.1906.8167

Sahly, A. 1966, Les Mains mutilées dans l'art préhistorique. Toulouse/Tunis, Privat/Maison tunisienne de l'édition, 317 p. (in French) ("Mutilated hands in prehistoric art")

San Juan-Foucher, C. 2006, Industrie osseuse décorée du Gravettien des Pyrénées. Munibe. Homenaje al Prof. Jesús Altuna. 2005-2006, 57(3: Arte, Antropología y Patrimonio arqueológico): 95-111. (in French) ("Gravettian decorated bone industry in the Pyrinees") URL: http://hal.archives-ouvertes.fr/hal-00495373/fr/

San Juan-Foucher, C. 2011, Industrie osseuse décorée et parures gravettiennes de Gargas (Hautes-Pyrénées, France): marqueurs culturels, sociaux et territoriaux. In: À la recherche des identités gravettiennes : actualités, questionnements et perspectives. Actes de la table ronde sur le Gravettien en France et dans les pays limitrophes, Aix-enProvence, 6-8 octobre 2008. (Goutas, N., Klaric, L., Pesesse, D., Guillermin, P., Eds.), Mémoire Vol 52, Éd. Société préhistorique française, Joué-lès-Tours: p. 225-241. (in French) ("Gravettian decorated bone industry and adorments from Gargas (Hautes- 
Pyrénées, France): cultural, social and territorial markers") URL: http://hal.archivesouvertes.fr/hal-00831887

San Juan-Foucher, C. 2013, Industria ósea decorada y arte mueble del Gravetiense pirenaico : perspectivas territoriales actualizadas. In: Pensando el Gravetiense : nuevos datos para la región cantábrica en su contexto peninsular y pirenaico. Actas del coloquio de Altamira, 20-22 de octubre 2011 (de las Heras, C. , Lasheras, J.-A., Arrizabalaga, A., de la Rasilla, M., Eds.), Monografías del Museo Nacional y Centro de Investigación de Altamira, Vol. 23, p. 438-460. (in Spanish) ("Decorated bone industry and portable art of the Pyrenian Gravettian: updated territorial perspectives")

San Juan-Foucher, C., Foucher, P. 2010, Marine Shell Beads from the Gravettian at Gargas Cave (Central Pyrenees, France): cultural and territorial markers. In: Not only Food. Marine, Terrestrial and Freshwater Molluscs in Archaeological Sites. Proceedings of the 2nd Meeting of the ICAZ Archaeomalacology Working Group (Santander, February 19th-22nd 2008) (Álvarez-Fernandez E. \& Carvajal-Contreras D., Eds) Munibe, suplemento 31: 28-35.

URL: http://www.aranzadi.eus/fileadmin/docs/Munibe/2010001309.pdf

Séronie-Vivien, M. 1994, Pétrographie des silex préhistoriques du gisement paléolithique de l'abri Dufaure (Sorde l'Abbaye, Landes). Bulletin de la Société linnéenne de Bordeaux., 22(1): p. 23-29. (in French) ("Petrography of the prehistoric flint from the Palaeolithic site of the Dufaure shelter (Sorde Abbey, Landes)")

Séronie-Vivien, M., Séronie-Vivien, M.-R. 1987, Le silex du Mésozoö̈que nord-aquitain. (supplément au t. 15 de La Société Linéenne de Bordeaux, Bordeaux, 132 p., 38 pl. (in French) ("The flint from the north-Aquitania Mesozoic")

Séronie-Vivien, M \& M.R., Foucher, P. 2006, L'économie du silex au Paléolithique supérieur dans le Bassin d'Aquitaine. Le cas des silex à lépidorbitoïdes des Pyrénées centrales Caractérisation et implications méthodologiques. PALEO. Revue d'archéologie préhistorique, 18: 193-215, 10 fig. (in French) ("Flint economy of upper Paleolithic in the Aquitaine basin. The case of lépidorbitoïde flint of Pyrénées centrales.

Méthodological implications and caracterization") URL: http://paleo.revues.org/316

Séronie-Vivien, M.-R., Séronie-Vivien, M., Foucher, P., Millet, D., Millet, F. 2012, From the Adour valley to the Gelise valley (western part of the Gers department): an important occurrence of siliceous raw material of Senonian origin. PALEO. Revue d'archéologie préhistorique , 23: 357-366. URL: http://paleo.revues.org/2474

Simonet, A. 2009, Les Gravettiens des Pyrénées : des armes aux sociétés. Thèse de doctorat, Université de Toulouse 2-le Mirail, 391 p. (in French) ("The Gravettiens of the Pyrenees: from weapons to societies")

Simonnet, R. 1967, L'abri sous roche Rhodes II et la question de l'Azilien dans les Pyrénées françaises. Note préliminaire. Bulletin de la Société préhistorique française, 175-186. (in French) ("The rockshelter Rhodes II and the question of the Azilian in the French Pyrenees. Preliminary notes") doi:10.3406/bspf.1967.4110

Simonnet, R. 1969, Préhistoire du site de Foix. Bulletin de la Société Ariégeoise des Sciences, Lettres et Arts, 25(1969): 51-80. (in French) ("Prehistory of the Foix site")

Simonnet, R. 1973, Le Paléolithique supérieur entre l'Hers et la Garonne. In: Préhistoire et Protohistoire des Pyrénées françaises recueil de textes et catalogue, exposition:, Musée 
pyrénéen, Château de Lourdes, p. 39-44. (in French) ("The Upper Palaeolithic between the Hers and the Garonne")

Simonnet, R. 1976, Les gisements préhistoriques des gorges de la Save dans le massif de Lespugue-Montmaurin. In: IXè Congrès U.I.S.P.P., Nice, Livret-guide excursion A5, Diffusion Centre national de la recherche scientifique, Højbjerg. p. 117-122. ("The prehistoric sites of the Save grooves in the Lespugue-Montmaurin massive ")

Simonnet, R. 1981, Carte des gîtes à silex des Pré-Pyrénées. In: La Préhistoire en Quercy dans le contexte de Midi-Pyrénées, Congrès Préhistorique de France, MontaubanCahors 1979, Société Préhistorique Française, p. 308-323. (in French) ("Map of flint deposits from the Pre-Pyrenees")

Simonnet, R. 1982, Grandes lames de silex dans le Paléolithique supérieur des Pyrénées centrales. Préhistoire ariégeoise, Bulletin de la Société préhistorique Ariège-Pyrénées, 37: 61-106. (in French) ("The large flint blades in the Upper Palaeolithic of the central Pyrenees")

Simonnet, R. 1985, Le silex du Magdalénien final de la grotte des Églises dans le bassin de Tarascon-sur-Ariège. Préhistoire ariégeoise, Bulletin de la Société préhistorique Ariège-Pyrénées, 40: 71-97. (in French) ("Flint of the final Magdalenian from the cave of Églises in Tarascon-sur-Ariege basin")

Simonnet, R. 1994, Origine des matières premières. In: Hommes et bisons du Paléolithique moyen à Mauran (Haute-Garonne), (Farizy, C., David, F., Jaubert, J., Eds.), Supplément à Gallia Préhistoire Vol. 30, CNRS éditions, p. 100-103. (in French) ("The origin of the raw materials")

Simonnet, R. 1996, Approvisionnement en silex au Paléolithique supérieur: déplacements et caractéristiques physionomiques des paysages, l'exemple des Pyrénées centrales. In: Pyrénées Préhistoriques - Arts et Sociétés. Actes du 118 e congrès national des sociétés historiques et scientifiques, Pau 1993 (Delporte, H. \& Clottes, J., Eds.), Éditions du CTHS, Paris: p. 117-128. (in French) ("Supply with flint in the Upper Palaeolithic: movement and physiognomic characteristics of the landscapes, the example of the central Pyrenees")

Simonnet, R. 1999a, Le silex et la fin du Paléolithique supérieur dans le bassin de Tarasconsur-Ariège. Préhistoire ariégeoise, Bulletin de la Société préhistorique AriègePyrénées. 1998, 53: 181-222. (in French) ("Flint and the end of the Upper Palaeolithic in Tarascon-sur-Ariege basin")

Simonnet, R. 1999b, De la géologie à la Préhistoire: le silex des Prépyrénées. Résultats et réflexions sur les perspectives et les limites de l'étude des matières premières lithiques. PALEO. Revue d'archéologie préhistorique, 11: p. 71-88. (in French) ("From geology to prehistory: the flint of Pre-Pyrenees. Results and reflections on the perspectives and limitations of the study of lithic raw materials") doi:10.3406/pal.1999.1171

Simonnet, R. 2002, De la lithothèque à la grotte ornée. Espace réel et espace imaginaire, Bulletin de la Société préhistorique Ariège-Pyrénées, 2001, 56: 73-77. (in French) ("From the lithotheque to the painted caves. Real space and imaginary space")

Simonnet, R. 2003, Le silex dans le bassin sous-pyrénéen de la Garonne. Compléments. Bulletin de la Société préhistorique Ariège-Pyrénées, 2002, 57: 113-170. (in French) ("Flint in the sub-Pyrenean basin of the Garonne. Additions") 
Simonnet, R. 2003, Le silex du Magdalénien de la grotte de La Vache. In: La grotte de La Vache, (Clottes, J. \& Delporte, H., Eds.), Vol. 1, Ministère de la Culture. Gand: 142150. (in French) ("Magdalenian flint form the La Vache cave")

Simonnet, G., Simonnet, L. \& Simonnet, R. 1990, Art mobilier et art pariétal à Labastide. In: L'art des objets au Paléolithique. L'art mobilier et son contexte. Tome 1: L'art mobilier et son contexte, Actes du premier colloque international sur l'art mobilier paléolithique, Foix-Mas d'Azil, nov. 1987, p. 173-187. (in French) ("Portable art and parietal art at Labastide")

Tarriño Vinagre, A. 2006, El sílex en la Cuenca Vasco-Cantábrica y Pirineo Navarro: caracterización y su aprovechamiento en la Prehistoria. Museo nacional y centro de investigación de Altamira Monografías, Vol. 21, Ministerio de Cultura, Madrid, 263 p. (in Spanish) ("Flint in the Basque-Cantabrian basin and the Pyrenees Navarro: characterization and its use in prehistory")

Tarriño Vinagre, A., con la colaboración de Bon, F. \& Normand, C. 2007, Disponibilidad de sílex como materia prima en la Prehistoria del Pirineo occidental. In: Fronteras naturales y fronteras culturales en los Pirineos prehistóricos, , Actas de la reunión de Tarascon-sur-Ariège, mars 2004, (Cazals, N., González Urquijo, J., Terradas, X., Eds.), PUbliCan-Ediciones de la Universidad de Cantabria, p. 103-123. (in Spanish) ("The availability of flint as raw material in the western Pyrenees Prehistory")

Turq, A. 2000, Paléolithique inférieur et moyen entre Dordogne et Lot. Société des Amis du Musée National de Préhistoire et de la Recherche Archéologique (supplément à Paléo, 2), 456 p. (in French) ("The Lower and the Middle Paleolithic between Dordogne and Lot") URL: http://www.persee.fr/web/revues/home/prescript/issue/pal_11453370_2000_sup_2_1 